\title{
The Effectiveness of Ultraviolet, Ozonization and Reverse Osmosis as Disinfection Method in Drinking Water Refill Stations
}

\section{Sri Yusnita Irda Sari, ${ }^{1}$ Muhamad Iqbal, ${ }^{2}$ Adi Imam Cahyadi, ${ }^{3}$ Titik Respati, ${ }^{4}$ Ardini Raksanagara, ${ }^{1}$ Ridad Agoes $^{3}$}

${ }^{1}$ Department of Public Health, ${ }^{2}$ Master Program in Public Health Sciences, ${ }^{3}$ Department of Microbiology and Parasitology, Faculty of Medicine, Universitas Padjadjaran, Bandung, Indonesia, ${ }^{4}$ Department of Public Health, Faculty of Medicine, Universitas Islam Bandung, Bandung, Indonesia

\begin{abstract}
The number of drinking water refill stations (DWRS) was increased rapidly because high of mid-low urban community need to get affordable drinking water. Water treatment methods in DWRS are varying even many DWRS uses more than one disinfection method to increase the effectiveness. The quality of many DWRS productions was reported unstandardized, however not yet the study to evaluate the effects of the water treatment method used. This study aimed to compare the effectiveness of various water treatment methods in DWRS to identify which method is the most effective. The study used a cross-sectional approach conducted in 3 groups of water treatment methods, namely ultraviolet, ultraviolet + ozonization, and a combination of ultraviolet + ozonization + reverse osmosis with each group consisted of 40 DWRS. The survey was conducted in July-September 2017 in Bandung municipality by structured interview. Examination of microbiological parameters of raw and processed drinking water samples using membrane filter method. Water samples from raw water and drinking water from treatment process were taken from each DWRS to be tested for the microbiological parameter by using the membrane filter method. Comparison of the effectiveness was analyzed using the Wilcoxon rank sum test and assessment of log removal reduction. The result showed that there was significantly different in the effectiveness of coliform removal between the three groups. The improvement for controlling and training particularly for the procedure and maintenance of water treatment equipment to the owners/workers in DWRS is urgently needed as the concern of related authority. In conclusion, the water treatment method using ultraviolet is the most effective disinfection method compared to the combination with other methods. The usage of more that one method of water treatment at the same time relate to the lower percentage of the effectiveness compares to the usage of only one method.
\end{abstract}

Key words: Drinking water, ozonization, reverse osmosis, ultraviolet, water refill stations

\section{Efektivitas Ultraviolet, Ozonisasi, dan Reverse Osmosis sebagai Metode Desinfeksi Depot Air Minum Isi Ulang}

\begin{abstract}
Abstrak
Perkembangan depot air minum isi ulang (DAM) melaju dengan pesat karena masyarakat menengah ke bawah perkotaan membutuhkan air minum dengan harga yang terjangkau. Metode pengolahan air baku menjadi air minum di DAM bervariasi bahkan tidak jarang digunakan lebih dari satu metode desinfeksi untuk meningkatkan efektivitasnya. Kualitas produksi DAM banyak yang dilaporkan tidak sesuai dengan standar, namun belum terdapat penelitian yang mengevaluasi pengaruh metode pengolahan air yang digunakan. Penelitian ini bertujuan membandingkan efektivitas berbagai metode pengolahan air di DAM sehingga dapat diketahui metode apa yang paling efektif. Penelitian ini menggunakan pendekatan cross-sectional yang dilakukan pada 3 kelompok metode pengolahan air, yaitu ultraviolet, ultraviolet + ozonisasi, dan kombinasi ultraviolet + ozonisasi + reverse osmosis dengan tiap-tiap kelompok terdiri atas 40 DAM. Survei dilakukan pada Juli-September 2017 di Kota Bandung dengan melakukan wawancara terstruktur. Sampel air baku dan air minum hasil olahan diambil dari setiap DAM untuk diperiksa parameter mikrobiologinya menggunakan metode filter membran. Perbandingan efektivitas dianalisis menggunakan Wilcoxon rank sum test dan penilaian log removal reduction. Hasil penelitian menunjukkan bahwa terdapat perbedaan efektivitas yang signifikan pada ketiga kelompok terutama efektivitas terhadap coliform. Perlu upaya pengawasan dan pelatihan khususnya mengenai teknis pemakaian dan pemeliharaan alat pada pemilik/ pekerja DAM yang harus menjadi perhatian pemerintah dan pihak terkait. Simpulan, metode pengolahan air menggunakan ultraviolet merupakan metode desinfeksi yang paling efektif dibanding dengan kombinasi metode lain. Pemakaian lebih dari satu metode desinfeksi pada saat yang bersamaan menyebabkan persentase efektivitas menjadi lebih rendah dibanding dengan yang menggunakan hanya satu jenis metode desinfeksi.
\end{abstract}

Kata kunci: Air minum, depot air minum, ozonisasi, reverse osmosis, ultraviolet

Received: 19 January 2018; Revised: 8 December 2018; Accepted: 13 December 2018; Published: 31 December 2018

Correspondence: Sri Yusnita Irda Sari, dr., M.Sc. Department of Public Health, Faculty of Medicine, Universitas Padjadjaran. Jln. Prof. Eyckman No. 38, Bandung 40161, West Java, Indonesia. Mobile: +628122394038. E-mail: sri.yusnita@unpad.ac.id 


\section{Introduction}

Water is very important for human life as a basic and fundamental human need to support all of the daily activities to get survive. The importance of water in daily life should balance between appropriate quality and quantity. On the other hand, the availability of water sources such as groundwater and spring becoming restricted due to the increase of anthropogenic water contamination from improper treatment of industries and domestic waste. The local water company in Indonesia (perusahaan daerah air minum or PDAM) as the main supplier of clean water in the urban area is not capable to provide the whole community because of the limitation of raw water availability. ${ }^{1}$ Consequently, bottled water and drinking water refill stations (DWRS) had been more popular and increasing during the last decades to provide the community's need for drinking water supply.

Bottled water was produced for the first time in Indonesia during 1972 and during the progress of development the price of bottled water had been increasing significantly. The community started to find alternatives to provide their drinking water need. This condition had created the business of DWRS which offer an affordable price, particularly for mid-low income community. The drinking water refill stations are the small business that treat raw water into drinking water using refill container and started to be more popular during the economic crisis in 1998 as the alternative of cheaper drinking water supply compare to bottled water. Since 1999, DWRS were rapidly increasing in all over Indonesia particularly in the urban area. However, some studies from many cities had reported the quality of DWRS production were not always appropriate according to the guideline. ${ }^{2-8}$

West Java is the most populous province in Indonesia and Bandung as the capital city is also reported an increasing number of DWRS as the result of rapid urbanization. However, the result of annual inspection from the Bandung Health Office showed that in 2015 about 22.22\% of DWRS production still contaminated by coliform/E. coli, and the result of contamination was even increasing to be $55.22 \%$ in $2016 .{ }^{9}$

Some factors that might influence the quality of drinking water from DWRS production are hygiene sanitation in the stations, the quality of raw water and the choice of water treatment method. During the process of water treatment from raw water into drinking water, the quality of the filtration unit and disinfection method are very essential to affect the result of drinking water production. ${ }^{9}$ However, no previous study had evaluated the comparison of effectiveness from many water treatment methods that popular to be used in Indonesia. Filtration process intends to separate the suspended particles and also to colloidal contaminants like microorganism in the water, while disinfection aims to exterminate the pathogens. Some methods that usually employ in DWRS are ultraviolet (UV), ozonization using $\mathrm{O}_{3}$ and reverse osmosis (RO) or the combination of these methods. ${ }^{10}$

Nowadays, RO as the ultrafiltration process is known as the most effective water treatment method. This process can eliminate 90-99\% of the contaminants in water. Wimalawansa ${ }^{11}$ reported that RO can decrease more than $95 \%$ of the potential toxic contaminants in water. This technology is widely used not only in big industries including bottled water but also more popular to be used as household water treatment. The osmotic pressure combine with other technology formulates this ultrafiltration becoming like the best filtration method to produce drinking water. However, besides the expensive of operational cost the other limitation of this process is the time of filtration. Since the diameter of the membrane was extremely small therefore the volume of water production is very small and need longer time, subsequently, additional power was needed to give more pressure so that the time to flow over the filter is faster. ${ }^{12}$

The ultrafiltration method or combination of ultrafiltration + ozonization are the most popular method that is used in DWRS since the operational cost is cheaper compare to RO. Until now, no study analyze the comparison of these water treatment method effectiveness in DWRS. This study aimed to identify which method as the most effective to eliminate the microbiological contaminants as the evidence to increase the quality control of DWRS production.

\section{Methods}

It was a quantitative study with a cross-sectional design, the analysis unit was registered DWRS in the Bandung Health Office. This study intended to compare the effectiveness of water treatment methods in DWRS to change the raw water into drinking water. The water treatment methods were determined into three (3) groups that were 
ultraviolet, the combination of ultraviolet + ozonization, and the combination of ultraviolet + ozonization + RO.

Minimal samples to compare the effectiveness in each group was calculated with alpha 0.05 and power of 0.80 resulted in the number of 34 DWRS as minimum samples in each group. Data from the Bandung Health Office reported that there were 659 registered DWRS listed in Bandung city during 2017. In this study, a total of 120 DWRS or 40 DWRS in each group were involved with random sampling method using the name list of registered DWRS in Bandung city. Randomization number was obtained from www.randomization.com.

The survey was conducted in July-September 2017 with two types of data collection that were water quality test and structured questionnairebased interview. In every selected DWRS, a set of the structured questionnaire consisted of demographical and characteristics data was interviewed to the owner of DWRS. Water samples from raw water and drinking water that produced in DWRS were collected using $200 \mathrm{~mL}$ sterile plastic container to examine the microbiological parameters (colony count of coliform and E. coli according to the guideline). Water samples were kept in the cool box before transported to the Microbiology and Parasitology Laboratory in Faculty of Medicine Universitas Padjadjaran.

Water samples were examined using the membrane filter method. This method grows the colony of coliform species by filtering 100 $\mathrm{mL}$ of water samples through a nitrocellulose membrane filter (diameter $47 \mathrm{~mm}$ with 0.45 $\mu \mathrm{m}$ micropores from Merck KGaA, Darmstadt,
Germany). The membrane was incubated using Chromocult ${ }^{\circledR}$ Coliform Agar (Merck KGaA, Darmstadt, Germany) for $24-48$ hours in $37 \pm 1^{\circ} \mathrm{C}$. The growth of coliform colony was identified in red colonies and $E$. coli in purple colonies. These colonies were determined using colony forming unit or CFU/100 mL.

The comparison of effectiveness from 3 groups was analyzed using the Wilcoxon rank sum test with $95 \%$ confident of the interval. Moreover, the effectiveness also compares based on log removal reduction (LRR), a method recommended by the World Health Organization (WHO) to evaluate the capability of the disinfection method to eliminate pathogens in water. This analysis used a logarithmic number of $\log 10$, the drinking water categorize safe if the effectiveness reaches minimal $4 \log 10$ or in other words the minimal of decimal elimination is 4 . The calculation of LRR based on an assumption of decrease number of pathogens. 1 log10 means 90\%, 2 log10 means 99\%, 3 log10 means 99.9\%, 4 log10 means $99.99 \%$, and $5 \log 10$ means $99.999 \%$. The water treatment method is good if the effectiveness reaches $4 \log 10$ and $5 \log 10$ and recommend as safe drinking water to be consumed.

This study started after obtaining ethics approval from the Health Research Ethics Committee of the Faculty of Medicine, Universitas Padjadjaran Bandung with a letter-number: 239/ UN6.10/ PN/2017.

\section{Results}

Total of 120 DWRS was selected and consisted of 40 DWRS with ultraviolet, 40 DWRS with ultraviolet + ozonization, and 40 with the

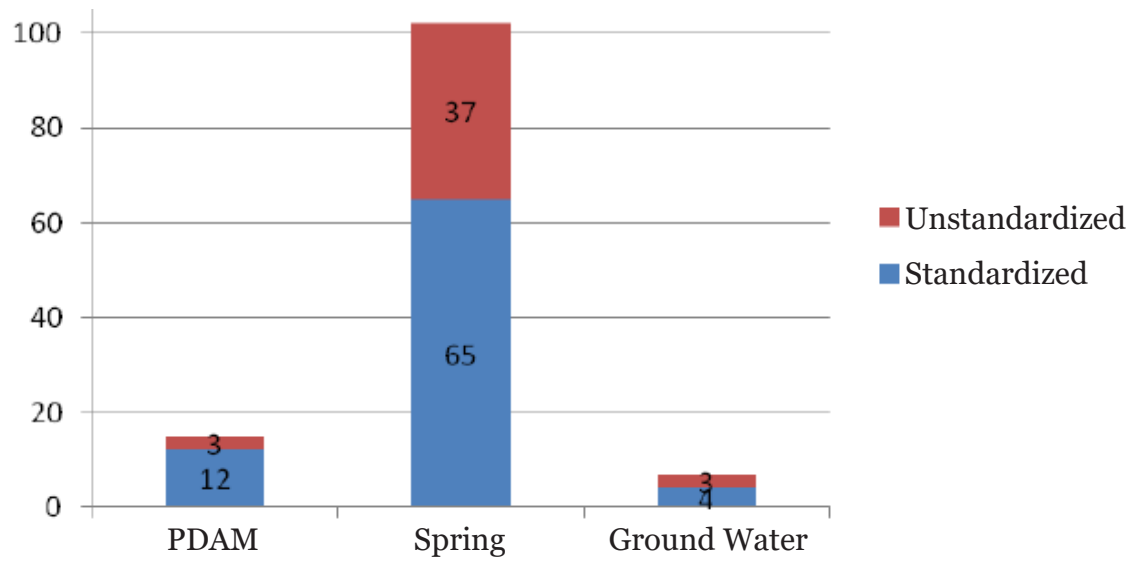

Figure 1 The Quality of Raw Water 
Table 1 Characteristics of Drinking Water Refill Stations

\begin{tabular}{|c|c|c|c|}
\hline Variables & $\begin{array}{c}\text { Ultraviolet } \\
\mathbf{n = 4 0}(\%)\end{array}$ & $\begin{array}{c}\text { Ultraviolet }+ \\
\text { Ozonization } \\
\text { n=40 (\%) }\end{array}$ & $\begin{array}{c}\text { Combination } \\
\text { of Ultraviolet }+ \\
\text { Ozonization + RO } \\
\text { n=40 (\%) } \\
\end{array}$ \\
\hline \multicolumn{4}{|c|}{ Number of worker (person) } \\
\hline 1 & $20(50)$ & $14(35)$ & $6(15)$ \\
\hline $2-3$ & $17(42.5)$ & $23(57)$ & $27(67.5)$ \\
\hline$>3$ & $3(7.5)$ & $3(8)$ & $7(17.5)$ \\
\hline \multicolumn{4}{|c|}{ Duration of business (years) } \\
\hline$<5$ & $21(51)$ & $12(30)$ & $19(47.5)$ \\
\hline $5^{-10}$ & $13(33)$ & $21(51)$ & $16(40)$ \\
\hline$>10$ & $6(16)$ & $7(19)$ & $5(12.5)$ \\
\hline \multicolumn{4}{|l|}{ Raw water sources } \\
\hline Tap water (PDAM) & $2(5)$ & $1(2.5)$ & $8(2)$ \\
\hline Spring & $36(90)$ & $37(92.5)$ & $29(72.5)$ \\
\hline Ground water & $2(5)$ & $2(5)$ & $3(7.5)$ \\
\hline \multicolumn{4}{|l|}{ Legal document } \\
\hline \multicolumn{4}{|l|}{ Business license } \\
\hline Available & $10(25)$ & $12(30)$ & $15(37.5)$ \\
\hline No available & $30(75)$ & $28(70)$ & $25(62.5)$ \\
\hline \multicolumn{4}{|c|}{$\begin{array}{l}\text { Certificate of proper hygiene } \\
\text { and sanitation }\end{array}$} \\
\hline Available & $7(17.5)$ & $5(12.5)$ & $12(30)$ \\
\hline No available & $33(82.5)$ & $35(87.5)$ & $28(70)$ \\
\hline \multicolumn{4}{|c|}{ Standard operating procedure } \\
\hline Available & $4(10)$ & $2(5)$ & $5(12.5)$ \\
\hline No available & $36(90)$ & $38(95)$ & $35(87.5)$ \\
\hline \multicolumn{4}{|l|}{ Production protocols } \\
\hline Available & $11(27.5)$ & $8(20)$ & $15(37.5)$ \\
\hline No available & $29(72.5)$ & $32(80)$ & $25(62.5)$ \\
\hline \multicolumn{4}{|l|}{ Laboratory test } \\
\hline \multicolumn{4}{|l|}{ Last 3 months } \\
\hline Yes & $10(25)$ & $10(25)$ & $2(5)$ \\
\hline No & $30(75)$ & $30(75)$ & $38(95)$ \\
\hline \multicolumn{4}{|l|}{ Last 6 months } \\
\hline Yes & $6(15)$ & $14(35)$ & $8(20)$ \\
\hline No & $34(85)$ & $26(65)$ & $32(80)$ \\
\hline \multicolumn{4}{|l|}{ Source of information } \\
\hline \multicolumn{4}{|l|}{ The owner of DWRS } \\
\hline Yes & $24(60)$ & $29(72.5)$ & $30(75)$ \\
\hline No & $16(40)$ & $11(27.5)$ & $10(25)$ \\
\hline \multicolumn{4}{|l|}{ Training/workshop } \\
\hline Yes & $14(35)$ & $21(52.5)$ & $22(55)$ \\
\hline No & $26(65)$ & $19(47.5)$ & $18(45)$ \\
\hline \multicolumn{4}{|l|}{ Employee coaching } \\
\hline Yes & $19(47.5)$ & $25(62.5)$ & $25(62.5)$ \\
\hline No & $21(52.5)$ & $15(37.5)$ & $15(37.5)$ \\
\hline
\end{tabular}

combination of ultraviolet + ozonization + RO. In particular, for the group of combination between ultraviolet, ozonization, and RO, only one DWRS that use only RO, 20 DWRS used ultraviolet + RO, 9 DWRS used ozonization + RO, and 10 DWRS used the combination of ultraviolet + ozonization + RO. The characteristic of these groups as described in Table 1.

Raw water source from spring water was dominantly used by DWRS, commonly it comes from foothill area near Bandung city, either in the north part or east part of Bandung area. The 


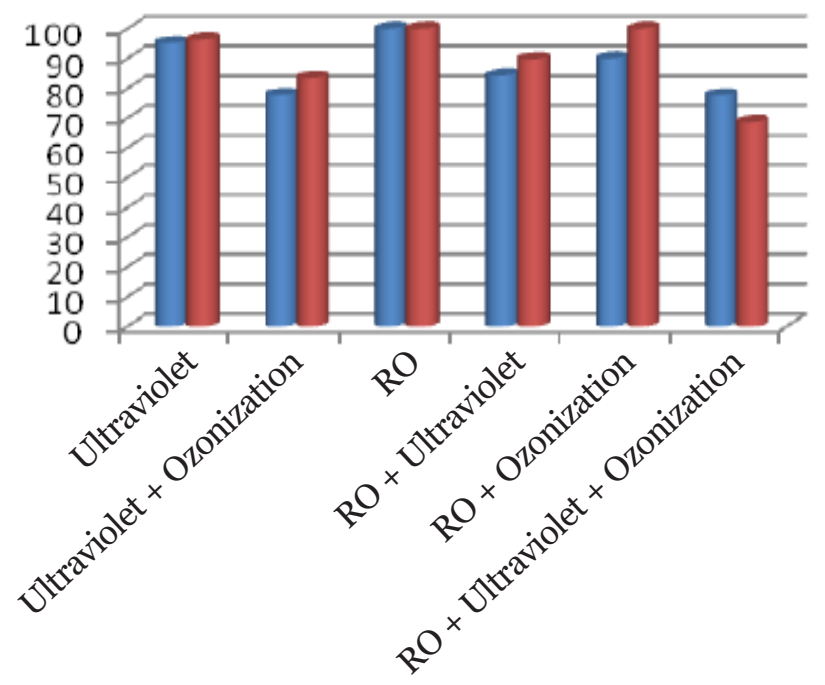

Effectiveness of Coliform

Removal

Effectiveness of $E$. coli Removal

Figure 2 Percentage of Effectiveness in Various Disinfection Methods in Refill Drinking Water Stations

quality of raw water according to clean water guideline (based on Ministry of Health Republic of Indonesia Regulation number 416 the year 1990 $)^{13}$ explained in Figure 1 according to the microbiological parameter.

The standard of Ministry of Health Republic of Indonesia and WHO guideline regulate that coliform and $E$. coli should be o (nil) in drinking water. WHO also divide the risk of having waterborne diseases due to consuming contaminated drinking water based on the number of fecal pathogens (E. coli). The classifications are low risk (1-9 E. coli/100 mL), moderate risk (10-99 E. coli/100 $\mathrm{mL}$ ), and high risk ( $\geq 100 \mathrm{E}$. coli/100 $\mathrm{mL}) .{ }^{14}$ The quality of microbiology parameter from 3 groups of water treatment methods in DWRS was illustrated in Table 2. Only 50\% of ultraviolet + ozonization method produced drinking water according to the standard, and
$10 \%$ of the water sample from this method had moderate and high risk. Ultraviolet as a single water treatment method showed better drinking production compare to combination with other methods.

The effectiveness of disinfection methods is determined by the percentage of coliform and $E$. coli removal number by analyzing the difference of the total number between the colony in raw water and drinking water production. The comparison of various disinfection method in DWRS illustrated in Figure 2. The average effectiveness of all type of combination $\mathrm{RO}$ method was $88 \%$ for coliform removal and $89.6 \%$ for $E$. coli removal, however, if we analyze in details we found that the effectiveness of RO decreased if we use it in combination with other methods, but the effectiveness of RO as single method could achieve 100\%. Furthermore,

Table 2 The Quality of Microbiological Parameter of Water Treatment Method in Drinking Water Refill Stations

\begin{tabular}{lccc}
\hline Indicator & $\begin{array}{c}\text { Ultraviolet } \\
\mathbf{n = 4 0 ( \% )}\end{array}$ & $\begin{array}{c}\text { Ultraviolet } \\
\text { Ozonization } \\
\mathbf{n = 4 0 ( \% )}\end{array}$ & $\begin{array}{c}\text { Combination of Ultraviolet } \\
\text { + Ozonization + RO } \\
\mathbf{n = 4 0 ( \% )}\end{array}$ \\
\hline Standardized & $29(72.5)$ & $20(50)$ & $30(75)$ \\
Unstandardized & & & $2(5)$ \\
$\quad$ No risk & $7(17.5)$ & $10(25)$ & $6(15)$ \\
Low risk & $4(10)$ & $6(15)$ & $2(5)$ \\
Moderate risk & 0 & $3(7.5)$ & 0 \\
$\quad$ High risk & 0 & $1(2.5)$ & \\
\hline
\end{tabular}


Table 3 Comparison of Ultraviolet, Ozonization, and Reverse Osmosis Effectiveness

\begin{tabular}{|c|c|c|c|c|c|c|c|c|}
\hline \multirow{2}{*}{$\begin{array}{l}\text { Disinfection } \\
\text { Method }\end{array}$} & \multicolumn{4}{|c|}{ Effectiveness of Coliform Removal } & \multicolumn{4}{|c|}{ Effectiveness of $E$. coli Removal } \\
\hline & $\begin{array}{c}\text { Mean } \\
\text { (SD) }\end{array}$ & $95 \% \mathrm{CI}$ & $\begin{array}{l}\text { Mean } \\
\text { Square }\end{array}$ & $\begin{array}{c}\mathbf{p} \\
\text { Value }\end{array}$ & $\begin{array}{c}\text { Mean } \\
\text { (SD) }\end{array}$ & $95 \% \mathrm{CI}$ & $\begin{array}{l}\text { Mean } \\
\text { Square }\end{array}$ & $\begin{array}{c}\mathbf{p} \\
\text { Value }\end{array}$ \\
\hline Ultraviolet & $\begin{array}{c}95 \cdot 3 \\
(15.1)\end{array}$ & $90.5^{-100}$ & & & $\begin{array}{c}96.3 \\
(16.2)\end{array}$ & $91.1-100$ & & \\
\hline $\begin{array}{l}\text { Ultraviolet + } \\
\text { ozonization }\end{array}$ & $\begin{array}{c}77.1 \\
(34.2)\end{array}$ & $66.3-87.9$ & $3,353.4$ & 0.019 & $\begin{array}{c}84.1 \\
(31.7)\end{array}$ & $74.1-94.1$ & $1,651.9$ & 0.120 \\
\hline $\begin{array}{l}\mathrm{RO}+ \\
\text { ultraviolet + } \\
\text { ozonization }\end{array}$ & $\begin{array}{c}85 \cdot 3 \\
(31.9)\end{array}$ & $74.9-95.6$ & & & $\begin{array}{c}87.1 \\
(31.9)\end{array}$ & $76.8-97.3$ & & \\
\hline
\end{tabular}

comparison of effectiveness in 3 disinfection methods was analyzed by Wilcoxon rank sum, the result showed that significantly different found for coliform removal with $\mathrm{p}=0.019$ as described in Table 3.

The comparison of effectiveness in various water treatment method can be analyzed using log removal with logarithmic scale since the number of colony removal were enormous. Comparison of between the three groups of disinfection methods explained in Table 4. Ultraviolet and a combination of $\mathrm{RO}+$ ultraviolet + ozonation have the highest percentage for LRR $5 \log 10$ both in the removal of coliform or E. coli. The combination of ultraviolet + ozonization showed only $50 \%$ achieved $5 \log 10$ to reduce coliform and only $75 \%$ to reduce $E$. coli. These result showed that the effectiveness of the combination in more than one water treatment method might be not efficient.

\section{Discussion}

Refill drinking water is popularly consumed by the lower middle-class community. Moreover, the phenomenon of rapid urbanization also influences the increase in DWRS in urban areas. Based on the characteristics in Table 1, the type of DWRS business is a small business with one or two workers. The compliance of the owners to gain the legal aspect such as business license and certificate of proper hygiene and sanitation was found low, moreover, only a few DWRS having the standard operating procedure with a clear flow of work for every step and maintenance process.

Even though the government had issued Ministry of Health Republic of Indonesia

Table 4 Comparison of Log Removal in Various Disinfection Method

\begin{tabular}{|c|c|c|c|}
\hline Log Removal & $\begin{array}{l}\text { Ultraviolet } \\
\mathrm{n}=\mathbf{4 0}(\%)\end{array}$ & $\begin{array}{c}\text { Ultraviolet }+ \\
\text { Ozonization } \\
\text { n=40 (\%) }\end{array}$ & $\begin{array}{c}\text { RO + Ultraviolet + } \\
\text { Ozonization } \\
\text { n=40 (\%) }\end{array}$ \\
\hline \multicolumn{4}{|l|}{ Coliform } \\
\hline $0 \log _{10}$ & $2(5)$ & $12(30)$ & $7(17.5)$ \\
\hline $1 \log 10$ & $5(12.5)$ & $6(15)$ & $1(2.5)$ \\
\hline $2 \log 10$ & $3(7.5)$ & $1(2.5)$ & $1(2.5)$ \\
\hline $3 \log 10$ & $0(0)$ & $1(2.5)$ & $\mathrm{o}(\mathrm{o})$ \\
\hline $4 \log 10$ & $o(0)$ & $\mathrm{o}(\mathrm{o})$ & o (o) \\
\hline $5 \log 10$ & $30(75)$ & $20(50)$ & $31(77.5)$ \\
\hline \multicolumn{4}{|l|}{ E. coli } \\
\hline o log10 & $1(2.5)$ & $8(20)$ & $5(12.5)$ \\
\hline $1 \log 10$ & $3(7.5)$ & $2(5)$ & $3(7.5)$ \\
\hline $2 \log 10$ & $\mathrm{o}(\mathrm{o})$ & $o(0)$ & $\mathrm{o}(\mathrm{o})$ \\
\hline $3 \log 10$ & $o(0)$ & $o(0)$ & $0(0)$ \\
\hline $4 \log 10$ & $\mathrm{o}(\mathrm{o})$ & $\mathrm{o}(\mathrm{o})$ & $\mathrm{o}(\mathrm{o})$ \\
\hline $5 \log 10$ & $36(90)$ & $30(75)$ & $32(80)$ \\
\hline
\end{tabular}


Regulation number 43 the year 2014 about hygiene and sanitation in DWRS, ${ }^{15}$ nevertheless the implementation had not been accomplished by all the owners of DWRS. The result showed that only $25 \%$ of DWRS routinely test the quality of drinking water production in the laboratory during the last 3 months, moreover only $5 \%$ of DWRS using the combination of RO tested the drinking water quality and only $15-35 \%$ of DWRS tested during the last 6 months. This fact provides evidence that in addition to low compliance with regulations, there is a mistaken belief among owners of the effectiveness of the disinfection method which may be caused by a lack of dissemination of information from the authorities regarding regulations to DWRS owners and workers. Lack of quality control from the government and no local regulation toward the law enforcement might also influence the quality of drinking water from DWRS production that consumes by the community. ${ }^{16}$

The selection of raw water is an important factor to be concerned by the DWRS owners, the better the raw water quality will produce a better quality of the drinking water. The examination from 3 types of raw water that usually use in DWRS showed that spring water had the highest percentage of unstandardized quality. Commonly, the community perception about the spring water quality was better compared to other water sources so that this type of raw water is customarily used by the community. All type of raw water that was used by DWRS should be in line with the health standard with the certificate of good quality from the standardized laboratory. Moreover, the transportation process should be noticed as a crucial phase that might influence the quality of raw water. Most of DWRS owners still not aware of this, even they do not know the name of the company that supplies raw water to their DWRS.

In practicality, many of DWRS owners combine more than one method to get more effectiveness. Figure 2 illustrated comparison of the various combination of disinfection method. DWRS that only use RO reach $100 \%$ effectiveness to remove coliform and E. coli, while DWRS that only use ultraviolet method reach 95\%. Combination of more than one method in the same time resulting in lower effectiveness between 77-89\%, even combination of 3 methods (RO + ultraviolet + ozonisasi) only reaches $77 \%$ of coliform removal and $68 \%$ of $E$. coli removal. This result contradictory with previous study that revealed combination of ultraviolet $+\mathrm{RO}$ effective to treat raw water from river or irrigation water to be drinking water with good quality with relatively low price of operational cost. ${ }^{18}$ Low effectiveness of combination methods might be due to inaccuracy in technical step during installation or lack of the owners awareness to check and carry out routine maintenance since they already use more than one disinfection methods.

Many DWRS choose to combine ultraviolet and ozonization method to increase the effectiveness. The quality of ultraviolet is affected by the speed of water flow, capacity or volume of ultraviolet emission and the intensity of the lamp. The limitation of ultraviolet is ineffectiveness to remove a certain type of spores and viruses, furthermore, it needs a source of energy and no residue of ultraviolet might initiate recontamination to the water..$^{17,18}$ Disinfection process with ozonization takes place in the ozone mixing tank. Data in Table 2 illustrated that percentage of unstandardized drinking water quality using a combination of ultraviolet and ozonization was the highest, even $10 \%$ of water samples having the high number of $E$. coli and categorize of medium and high risk to transmit water-borne diseases.

The process of reverse osmosis uses high pressure to make raw water can pass the specific semipermeable membrane with extremely small pores (0.0001 microns). This small pores produce only $\mathrm{H}_{2} \mathrm{O}$ could pass the membrane, while bacteria, viruses, and chemicals are filtered and removed through a certain channel as discharge out pipe. ${ }^{21}$ Until now, reverse osmosis is known as the best disinfection method as ultrafiltration to produce drinking water with the highest purity, however this method need high energy to generate high pressure to push raw water passes through the semipermeable membrane, consequently this process also generate high volume of fluid waste with high concentrations of toxin and need high operational cost. The result in Table 2 showed that the percentage of standardizing drinking water between ultraviolet and combination of ultraviolet + ozonization + RO was similar. This result was not in line with the previous study that proved RO as the most effective method compare to others and ultraviolet still leave $31 \%$ of the pathogen in drinking water production. ${ }^{19}$

Table 3 revealed that effectiveness from various disinfection method significantly varies 
in coliform removal. In Table 4, LRR of ultraviolet + ozonization that inline with standard or reach $5 \log 10$ was only $50 \%$. The previous study found many DWRS with other methods besides RO still produce coliform contaminated drinking water. ${ }^{19,21}$ However, in this study, the usage of a single water treatment method is better compared to the combination of two or three methods. The percentage of DWRS that only used ultraviolet method reached higher 5 log10 LRR compare to other combination methods. This might be the effect of less maintenance process when two or more methods used in the same time since the owners of DWRS belief that more than one method should increase the effectiveness and this belief make them neglect the maintenance of each method.

The effort to increase quality control by the government in an integrated system in collaboration with the owners and consumers should be intensified. Training and supervision particularly regarding controlling and maintenance of disinfection unit should be scheduled regularly and accessible by all DWRS. Drinking water is essential for human life so any risk, although small should be prevented include ineffectiveness of disinfection methods.

Further development of trainings for owners and workers in DWRS is urgently needed in term of technical coaching about water treatment to prevent the production of unstandardize drinking water. The government should develop integrated supervision system to protect the consumers.

\section{Conclusions}

The water treatment method using ultraviolet is the most effective disinfection method compared to the combination with other methods. The operation of more than one method of water treatment in the same time in drinking water refill stations might decrease effectiveness of water treatment method.

\section{Conflict of Interest}

The authors declare no conflict of interests.

\section{Acknowledgement}

This study was part of Lecturer Competency Research Grant entitled "Prediction Model of Refill Drinking Water Station Production and Development of Integrated Surveillance System." The researchers would like to thank the Directorate of Research, Community Services and Innovation, Universitas Padjadjaran, Bandung for the funding support from Internal Research Grant year 2017-2018. We also appreciate the support from all primary health care sanitarians, staffs of Bandung City Health Office and all staffs in the laboratory for the hard work of this study.

\section{References}

1. Badan Peningkatan Penyelenggaraan Sistem Penyediaan Air Minum, Kementerian Pekerjaan Umum Dan Perumahan Rakyat. Buku kinerja PDAM 2017 [cited 2017 October 12]. Available from: http://sim.ciptakarya. pu.go.id/bppspam/assets/assets/upload/ BUKU_Lap_Kinerja_PDAM_2017_FA.pdf.

2. Sangande JB, Pinontoan OR, Rimper JRTSL. Uji kualitas bakteriologi depot air minum isi ulang di Kecamatan Amurang dan Kecamatan Tumpaan Kabupaten Minahasa Selatan tahun 2017. KESMAS. 2017;6(4):1-7.

3. Suprihatin B, Adriyani R. Higiene sanitasi depot air minum isi ulang di Kecamatan Tanjung Redep Kabupaten Berau Kalimantan Timur. JKL. 2008;4(1):81-8.

4. Khoeriyah A, Anies. Aspek kualitas bakteriologis depot air minum isi ulang (DAMIU) di Kabupaten Bandung Barat. MKB. 2015;47(3):137-43.

5. Wulandari S, Siwiendrayanti A, Wahyuningsih AS. Higiene dan sanitasi serta kualitas bakteriologis DAMIU di sekitar Universitas Negeri Semarang. UJPH. 2015;4(3):8-15.

6. Astuti SD, Suhartono, Suwondo A. Faktorfaktor yang berhubungan dengan angka kuman dalam air produk air minum isi ulang di Pemalang. JKLI. 2014;13(1):20-5.

7. Adelina R, Winarsih, Setyorini HA. Penilaian air minum isi ulang berdasarkan parameter fisika dan kimia di dan luar Jabodetabek tahun 2011. JKI. 2012;2(2):48-53.

8. Enjelina W, Purba MS, Erda Z. Faktor higiene sanitasi yang berhubungan dengan kualitas bakteriologi air minum isi ulang di Kota Tanjungpinang. JKMA. 2016;11(1):33-8.

9. Dinas Kesehatan Kota Bandung. Laporan tahunan Seksi Penyehatan Lingkungan Dinas Kesehatan Kota Bandung. Bandung: Dinas Kesehatan Kota Bandung; 2015. 
10. Direktorat Jenderal Pengendalian Penyakit dan Penyehatan Lingkungan (Ditjen PP dan PL), Departemen Kesehatan Republik Indonesia. Pedoman pelaksanaan penyelenggaraan hygiene sanitasi depot air minum. Jakarta: Ditjen PP dan PL, Departemen Kesesehatan RI; 2006.

11. Wimalawansa SJ. Purification of contaminated water with reverse osmosis: effective solution of providing clean water for human needs in developing countries. IJETAE. 2013;3(12):75-89

12. Konieczny K, Rajca M, Bodzek M, Kwiecińska A. Water treatment using hybrid method of coagulation and low-pressure membrane filtration. Environ Prot Eng. 2009;35(1):522.

13. Peraturan Menteri Kesehatan Republik Indonesia Nomor: 416/MEN.KES/PER/ IX/1990 tentang Syarat-syarat dan Pengawasan Kualitas Air.

14. World Health Organization (WHO). Guidelines for drinking-water quality. $4^{\text {th }}$ Edition. Geneva: WHO Press; 2011.

15. Peraturan Menteri Kesehatan Republik Indonesia Nomor 43 Tahun 2014 tentang Higiene Sanitasi Depot Air Minum.

16. Raksanagara AS, Fitriyah S, Afriandi I,
Sukandar H, Sari SYI. Aspek internal dan eksternal kualitas produksi depot air minum isi ulang: studi kualitatif di Kota Bandung. MKB. 2018;50(1):53-60

17. Linden $\mathrm{KG}$, Rosenfeldt EJ. Ultraviolet light processes. In: Edzwald JK, editor. Water quality \& treatment: a handbook on drinking water. $6^{\text {th }}$ Edition. New York: McGraw-Hill; 2010. p. 18.1-37.

18. Utami EAY, Moesriati A, Karnaningroem N. Risiko kegagalan pada kualitas produksi air minum isi ulang di Kecamatan Sukolilo Surabaya menggunakan failure mode and effect analysis (FMEA). Jurnal Teknik ITS. 2016;5(2):F-279-83.

19. Latif IW. Studi kualitas air minum isi ulang ditinjau dari proses ozonisasi, ultraviolet, dan reversed osmosis di Kecamatan Kota Tengah dan Kecamatan Kota Selatan Kota Gorontalo 2012. PHJ. 2012;1(1):57-62.

20. Said NI. Disinfeksi untuk proses pengolahan air minum. JAI. 2007;3(1):15-26.

21. Wandrivel R, Suharti N, Lestari Y. Kualitas air minum yang diproduksi depot air minum isi ulang di Kecamatan Bungus Padang berdasarkan persyaratan mikrobiologi. JKA. 2012;1(3):129-33. 